\title{
Rural Young Agri Entrepreneurs: Problems, Suggestions and Strategy for Successful Running of their Enterprise
}

\author{
G. Shivacharan*, V. Sudha Rani and R. Vasantha \\ Department of Agricultural Extension, Prof. Jayashankar Telangana State Agricultural \\ University, College of Agriculture, Rajendranagar, Hyderabad- 500030, Telangana, India \\ *Corresponding author
}

\section{A B S T R A C T}

Keywords

Agri entrepreneurship, Problems,

Suggestions, Strategy.

Article Info

Accepted:

04 September 2017

Available Online:

10 November 2017
Agri entrepreneurship is now a days a major opportunity for the people who lives in rural areas. On the contrary it is also a fact that the majority of rural entrepreneurs is facing many problems due to not availability of primary amenities in rural areas of developing country like India. This paper makes an attempt to find out the Problems and Strategy for the potentiality of agri Entrepreneurship in rural areas. It also focuses on the major technical problems, administrative and organizational problems, economic and social problems and financial problems faced by agri entrepreneurs, i.e. availability of raw material, electricity, water supply, lack of training support and labour shortage etc.

\section{Introduction}

Indian economy is basically agrarian economy. Over 85 per cent of the rural population in India is dependent on agriculture for livelihood but the contribution of agriculture in national income has declined to 26 per cent and that of service sector has increased to more than half of the total national income.

Uneducated and unskilled mass of India's population living in rural area is not fitting in to the employment market created by service sector growth. They are therefore depending on agriculture for their livelihood. With employment of more than 50 percent of labour force agriculture sector is major employment provider even today. The seasonal nature of agriculture and lack of irrigation facilities creates problem of seasonal and cyclical unemployment.

Large number of persons employed in agriculture is of disguised nature. They seem to be employed but their marginal productivity is zero.

Even if some of the farm rural youth shift from primary agriculture production activities to secondary agriculture (processing, value addition) and agri entrepreneurship, the present level of agriculture production may not get affected at all. 
The main objectives of this study are to analyze the problems of rural youth and their suggestions for successful running of their enterprise. And to develop a strategy for promotion of agri entrepreneurship development among rural youth.

\section{Results and Discussion}

\section{Problems of rural youth in running their enterprise}

\section{Technical problems}

It could be concluded from the Table 1 that majority $(50.83 \%)$ of the seed production, seed processing and rice mill entrepreneurs revealed that 'Interruption in power supply' was the major technical problem followed by 'Procurement of raw material is difficult' $(45.83 \%)$ in case of seed production, seed processing and rice mill entrepreneurs, 'Fear of crop failure due to climate change' $(44.17 \%)$ in case of seed production and seed processing entrepreneurs, 'Lack of skill oriented training programmes' $(40.83 \%)$ in case of seed production, seed processing, rice mill and poultry entrepreneurs, 'Pest and disease management in seed production during seasonal changes' $(35.00 \%)$ in case of seed production entrepreneurs, 'Lack of knowledge on supply chain management' $(20.00 \%)$ in case of seed processing and rice mill entrepreneurs and 'Foul diseases during climate changes in poultry' $(3.33 \%)$ in case of poultry entrepreneurs.

From the above results it could be inferred that majority $(50.83 \%)$ of the respondents revealed that 'Interruption in power supply' was the major technical problem the reason might be that there was severe power cut in rural areas.

\section{Administrative and organizational problems}

It could be concluded from the Table 1 that most $(27.50 \%)$ of the rice mill and seed processing entrepreneurs revealed that 'Seasonal supply of raw material' was the major administrative and organizational problem followed by 'Lengthy loan sanctioning procedure' $(23.33 \%)$ in case of rice mill, dairy and poultry entrepreneurs, 'Lack of storage facilities nearby' $(15.83 \%)$ in case of rice mill entrepreneurs, 'Seed distribution problem' (7.50\%) and 'Lack of organizations among entrepreneurs' (5.83\%) in case of seed processing entrepreneurs.

From the above results it could be inferred that most $(27.50 \%)$ of the respondents revealed that 'Seasonal supply of raw material' was the major administrative and organizational problem the reason might be that the agriculture is mostly seasonal based.

\section{Economic and social problems}

It could be concluded from the Table 1 that majority $(52.50 \%)$ of the seed production, seed processing and rice mill entrepreneurs revealed that 'Shortage of labour' was the major economic and social problem problem followed by 'Price fluctuations of product in the market $(35.83 \%)$ in case of vegetable commission agencis, seed processing and rice mill entrepreneurs, 'Lack of organized and regular market' $(32.50 \%)$ in case of seed processing, vegetable commission agencies and rice mill entrepreneurs, 'Heavy competition among entrepreneurs' (30.00\%) in case of rice mill, vegetable commission agencies and seed processing entrepreneurs, 'Absence of labour during festivals' (24.17\%) in case of seed processing and rice mill entrepreneurs, 'High feeding cost' $(8.33 \%)$ in case of poultry and dairy entrepreneurs, 'Low remunerative price for milk' $(6.67 \%)$ in case of dairy entrepreneurs and 'Low egg price during summer' $(3.33 \%)$ in case of poultry entrepreneurs.

From the above results it could be inferred that majority $(52.50 \%)$ of the respondents 
revealed that 'Shortage of labour' was the major economic and social problem the reason might be that there was migration of people from rural to urban areas.

\section{Financial problems}

It could be concluded from the Table 1 that most $(30.00 \%)$ of the rice mill, seed processing and dairy entrepreneurs revealed that 'Lack of working capital for running the enterprise' as a major financial problem in running the enterprise and 'Government has to increase processing fees' $(22.50 \%)$ in case of rice mill entrepreneurs.

From the above results it could be inferred that most $(30.00 \%)$ of the respondents revealed that 'Lack of working capital for running the enterprise' was a major financial problem the reason might be that the sanctioned loan was not sufficient for the management of enterprise. The above problems were partially confirmed with the Patel (2012) and Saxena (2012) study where entrepreneurial behaviour of rural women and problems of rural entrepreneurs was studied respectively.

\section{Suggestions of rural youth for successful running of their enterprise}

From the Table 2 it can be inferred that majority $(40.83 \%)$ of the s suggested that 'Provide skill oriented training programmes' followed by 'Improve technical knowhow knowledge' (35.83\%), 'Regular supply of electricity and water' $(35.00 \%)$, 'Simplify the loan sanctioning procedure' (35.00\%), 'Formation of organization or association to get help from all sources' (32.50\%), 'Need family support in enterprise management' (29.17\%), 'Government should encourage rural youth for promoting entrepreneurial activity' (26.67\%), 'Provide professional expertise on latest production and market trends' (21.67\%) and 'Contract farming has to come' $(20.00 \%)$.

\section{Strategy for promotion of agri entrepreneurship development among rural youth}

The following is the strategy depicting the interventions to be taken up by the various stakeholders of agri entrepreneurship development viz., public (public agencies, DIC's (District Industries Centres), DRDA (District Rural Development Agency), SMEDA (Small and Medium Entrepreneurs Development Agency), TCO's (Technical Consultancy Organizations), MSME (Micro Small and Medium Enterprises) development agencies and Entrepreneurship Development Institutes), private vocational training institutes, NGO's (Non-Government Organizations) and Institutions conducting Agri Clinics and Agri Business Centre training programmes.

This is evident from the findings that most of the respondents had high level of innovativeness, risk orientation, leadership ability, self-confidence and decision making ability therefore the DRDA, SMEDA, TCO's, MSME development agencies, Entrepreneurship Development Institutes should work in coherence/ collaboration to channelize these positive proactive entrepreneurial behaviour components of rural youth to encourage them to establish more agro-based enterprises. The Department of marketing, National Small Industries Corporation should establish more organized, regulated and controlled markets with better connectivity between rural and urban areas to facilitate to marketing of the products continuously without any intermediaries. 
Table.1 Problems elicited by rural youth in running their enterprise

\begin{tabular}{|l|l|c|c|c|c|}
\hline S. No. & \multicolumn{1}{|c|}{ Problem } & \multicolumn{1}{|c|}{ Type of enterprise } & \multicolumn{1}{|c|}{ Frequency } & Percentage & Rank \\
\hline 1 & $\begin{array}{l}\text { Lack of skill oriented training } \\
\text { programmes. }\end{array}$ & $\begin{array}{l}\text { Seed production, Seed } \\
\text { processing, Rice mill, Poultry. }\end{array}$ & 49 & 40.83 & IV \\
\hline 2 & $\begin{array}{l}\text { Interruption in power supply. } \\
\text { Seed production, Seed } \\
\text { processing, Rice mill. }\end{array}$ & 61 & 50.83 & I \\
\hline 3 & $\begin{array}{l}\text { Procurement of raw material is } \\
\text { Rice mill, Seed production. }\end{array}$ & 55 & 45.83 & II \\
\hline 4 & $\begin{array}{l}\text { Pest and disease management in seed } \\
\text { production during seasonal changes. }\end{array}$ & Seed production. & 42 & 35.00 & V \\
\hline 5 & $\begin{array}{l}\text { Fear of crop failure due to climate } \\
\text { change. }\end{array}$ & $\begin{array}{l}\text { Seed production, Seed } \\
\text { processing. }\end{array}$ & 53 & 44.17 & III \\
\hline 6 & $\begin{array}{l}\text { Foul diseases during climate changes } \\
\text { in poultry. }\end{array}$ & 4 & 3.33 & VII \\
\hline 7 & $\begin{array}{l}\text { Lack of knowledge on supply chain } \\
\text { management. }\end{array}$ & Seed processing, Rice mill. & 24 & 20.00 & VI \\
\hline
\end{tabular}

\begin{tabular}{|c|c|c|c|c|c|}
\hline \multicolumn{6}{|c|}{ 2. Administrative and Organizational problems } \\
\hline 1 & Seasonal supply of raw material. & Rice mill and Seed processing. & 33 & 27.50 & I \\
\hline 2 & Seed distribution problem. & Seed processing. & 9 & 7.50 & IV \\
\hline 3 & Lack of storage facilities nearby. & Rice mill. & 19 & 15.83 & III \\
\hline 4 & $\begin{array}{lll}\begin{array}{l}\text { Lack of } \\
\text { entrepreneurs. }\end{array} & \text { organizations among } \\
\end{array}$ & Seed processing. & 7 & 5.83 & $\mathbf{V}$ \\
\hline 5 & Lengthy loan sanctioning procedure. & Rice mill, Poultry and Dairy. & 28 & 23.33 & II \\
\hline \multicolumn{6}{|c|}{ 3. Economic and Social problems } \\
\hline 1 & Absence of labour during festivals. & Seed processing and Rice mill. & 29 & 24.17 & $\mathbf{V}$ \\
\hline 2 & Shortage of labour. & $\begin{array}{l}\text { Seed production, } \\
\text { processing and Rice mill. }\end{array}$ & 63 & 52.50 & I \\
\hline 3 & Low remunerative price for milk. & Dairy. & 8 & 6.67 & VII \\
\hline 4 & High feeding cost. & Poultry and Dairy. & 10 & 8.33 & VI \\
\hline 5 & $\begin{array}{l}\text { Price fluctuations of product in the } \\
\text { market. }\end{array}$ & $\begin{array}{l}\text { Rice mill, } \\
\text { commission agency } \\
\text { processing. }\end{array}$ & 43 & 35.83 & II \\
\hline 6 & Low egg price during summer. & Poultry. & 4 & 3.33 & VIII \\
\hline 7 & Lack of organized and regular market. & $\begin{array}{lll}\text { Seed processing, } & \text { vegetable } \\
\text { commission agency } & \text { and Rice } \\
\text { mill. }\end{array}$ & 39 & 32.50 & III \\
\hline 8 & Heavy competition among entrepreneurs. & $\begin{array}{l}\text { Rice mill, Seed processing and } \\
\text { vegetable commission agency. }\end{array}$ & 36 & 30.00 & IV \\
\hline \multicolumn{6}{|c|}{ 4.6.1.4 Financial problems } \\
\hline 1 & Government has to increase processing fees. & Rice mill. & 27 & 22.50 & II \\
\hline 4 & $\begin{array}{l}\text { Lack of working capital for running the } \\
\text { enterprise. }\end{array}$ & $\begin{array}{l}\text { Rice mill, Seed processing and } \\
\text { Dairy. }\end{array}$ & 36 & 30.00 & I \\
\hline
\end{tabular}


Table.2 Suggestions of rural youth for successful running of their enterprise $(N=120)$

\begin{tabular}{|c|c|c|c|c|}
\hline S. No. & Suggestion & Frequency & Percentage (\%) & Rank \\
\hline 1 & Contract farming has to come. & 24 & 20.00 & $\mathbf{X}$ \\
\hline 2 & $\begin{array}{l}\text { Formation of organization or association to get } \\
\text { help from all sources. }\end{array}$ & 39 & 32.50 & $\mathbf{V}$ \\
\hline 3 & $\begin{array}{l}\text { Government should encourage rural youth for } \\
\text { promoting entrepreneurial activity. }\end{array}$ & 32 & 26.67 & VII \\
\hline 4 & Provide skill oriented training programmes. & 49 & 40.83 & $\mathbf{I}$ \\
\hline 5 & Regular supply of electricity and water. & 42 & 35.00 & III \\
\hline 6 & $\begin{array}{l}\text { Provide professional expertise on latest } \\
\text { production and market trends. }\end{array}$ & 26 & 21.67 & IX \\
\hline 7 & Need family support in enterprise management. & 35 & 29.17 & VI \\
\hline 8 & Simplify the loan sanctioning procedure. & 42 & 35.00 & III \\
\hline 9 & \begin{tabular}{|l}
$\begin{array}{l}\text { Provide knowledge on supply chain } \\
\text { management. }\end{array}$ \\
\end{tabular} & 28 & 23.33 & VIII \\
\hline 10 & Improve technical knowhow knowledge. & 43 & 35.83 & II \\
\hline
\end{tabular}

All the agencies viz., public private and NGO's engaged in entrepreneurship development at district level must conduct capacity building programmme i.e. product oriented and process oriented EDP's (Entrepreneurship Development Programmes) for rural youth enabling them the right choice of entrepreneurial activity.

As the study indicated seasonal raw material supply Government agencies especially National Small Industries Corporation should take necessary steps for regular and adequate supply of raw material and provide cold storage facilities for agro produce. A special capacity building programme is necessary to strengthen the existing supply chains in agri enterprises and create awareness among rural youth and other stake holders about their role in effective supply chain management.

As the study revealed majority of the agro enterprises were of seed production and agro processing units, regular training programmes in these areas may be organized for rural youth for technology up gradation and quality maintenance. The study revealed that majority of the respondents had good buy back arrangements for their production, hence they may be encouraged to promote contract farming with small and marginal farmers for regular supply of raw material.

MSME development institutes, DIC's, DRDA and SMEDA must also include on farm entrepreneurial activities (agri enterprises) besides traditional off farm activities in their regular training and development programmes.

Presently ACABC's are providing trainings to agri graduates and those who complete agri polytechnic diploma only in various agri entrepreneurship activities, however it would be more appropriate and be fitting in the present scenario to consider educated rural youth for giving them training in agri entrepreneurship.

Dept. of agriculture and Horticulture may avail this opportunity and encourage contract farming and facilitate the rural entrepreneurs and the farmers in arriving beneficial longterm contract arrangements so that the entrepreneurs will have regular supply of raw material and the farmer will have the income. 
Study revealed medium level of entrepreneurial components viz., achievement motivation, management orientation and technology orientation, hence a special Achievement Training Programmes (AMT) having inbuilt enterprise management and technology management are highly essential.

It is indicated from the study of profile characters of respondents that most of the respondents have not undergone any training even if undergone only on knowledge aspects and the respondents also had low to very low entrepreneurial experience. Hence efforts should be made immediately by different agencies of agri entrepreneurship development including SAU's (State Agricultural Universities) and Dept. of Agriculture and Horticulture to take up skill based trainings and exposure visits to entrepreneurs and conduct interaction meetings with successful agri entrepreneurs.

Profile characters like extension contact, financial support and family support were in low to medium levels hence extension officers of public and private agencies must take up regular visits and create awareness among the entrepreneurs about the different Government policies, programmes, incentives and financial assistance provided for entrepreneurs by Govt. and credit agencies. This would enable rural youth to venture new innovative ideas with financial support of
Government and banks even in the event of low family support.

Public and private agri entrepreneurship development institutes should encourage entrepreneurs among rural youth to organize themselves into groups or clubs for better backward and forward linkages by channelizing their proactive profile characters i.e., socio political participation and economic motivation.

Broadly for promotion and development of agri entrepreneurship all the development efforts must work in Public Private Partnership (PPP) mode to avoid duplication of efforts and in bringing better synergetic effect of development efforts.

Knowing the problems and suggestions by the rural young agri entrepreneurs we could able to give the above strategy for successful running of their enterprises.

\section{References}

Patel, M.M.A.J., 2012. Entrepreneurial behaviour of rural women. Indian Research Journal of Extension Education. 12 (1): 55-59.

Saxena, S., 2012. Problems faced by rural entrepreneurs and remedies to solve it. IOSR Journal of Business and Management. 3: 23-29.

\section{How to cite this article:}

Shivacharan, G., V. Sudha Rani and Vasantha, R. 2017. Rural Young Agri Entrepreneurs: Problems, Suggestions and Strategy for Successful Running of their Enterprise. Int.J.Curr.Microbiol.App.Sci. 6(11): 259-264. doi: https://doi.org/10.20546/ijcmas.2017.611.031 